\title{
Active transportation to school for children and adolescents from Brazil: a systematic review
}

\section{Transporte ativo para escola de crianças e adolescentes do Brasil: uma revisão sistemática}

\author{
Gerson Luis de Moraes Ferrari1,2 \\ Eduardo Rossato de Victo ${ }^{2,3}$ \\ Tatiane Kosimenko Ferrari ${ }^{3,4}$ \\ Dirceu Solée
}

\begin{abstract}
The aim of this study was to describe the use of active transportation to school (ATS) for Brazilian children and adolescents through a systematic review. This review was carried out from February to March of 2018 by using databases from the area, governmental policies and research and by contacting researchers from this area. The databases used were: LILACS; BIREME; SCIELO; MEDLINE and SCOPUS. The search was performed in articles published from January 2007 to December 2017. The inclusion criteria were: original articles published in journals; articles that measured ATS; articles that evaluated Brazilian children and/or adolescents with ages ranging between 0 and 19 years of age, without specific clinical conditions, without diagnoses of diseases and non-athletes. Overall, 19 articles were selected for this study. Only 8 presented ATS values for gender, with boys and girls using ATS similarly, 4 for each gender. Regarding regions, 11 studies presented data from the Southern regions, 3 studies presented data from the Southeastern region, 3 from the Northeastern region and 2 studies presented data from Brazil as a whole. The Northern and Midwestern regions were not studied in any of the articles. Based on the results, the prevalence of ATS for children and adolescents varies according to the studies and regions in Brazil. Authorities should be encouraged to build monitoring systems for ATS to support planning and evaluation of public policies.
\end{abstract} Key words: Adolescents; Brazil; Children; Physical activity; Sedentary lifestyle.

Resumo - O objetivo desse estudo foi descrever o uso do transporte ativo para escola (TAE) em crianças e adolescentes brasileiros em uma revisão sistemática. A revisão foi realizada no periodo de vevereiro à março de 2018, utilizando bases de dados da área, e pesquisas políticas e governamentais através de pesquisadores da área. As bases de dados utilizadas foram: LILACS; BIREME; SCIELO; MEDLINE e SCOPUS. A busca foi realizada em artigos publicados no periodo de Janeiro de 2007 à Dezembro de 2017. Os critérios de inclusão foram: artigos originais publicados em periódicos; artigos que mediram TAE; artigos que avaliaram crianças e I ou adolescentes Brasileiros com idade entre 0 e 19 anos, sem condiçôes clínicas especificas, sem diagnósticos de doenças e não atletas. No total, 19 artigos foram selecionados para este estudo. Apenas 8 apresentaram valores de TAE conforme o sexo, sendo que meninos e meninas usaram TAE de forma semelhante, sendo 4 para cada sexo. Em relação às regióes, 11 estudos apresentaram dados das regióes do Sul, 3 estudos apresentaram dados da região Sudeste, 3 da região Nordeste e 2 estudos apresentaram dados do Brasil como um todo. As regiöes Norte e Centro-Oeste não foram analisadas em nenhum dos artigos. Com base nos resultados, a prevalência de TAE para crianças e adolescentes varia de acordo com os estudos e regióes no Brasil. As autoridades devem ser incentivadas a criar sistemas de monitoramento para o TAE para apoiar o planejamento e a avaliação de politicas públicas.

Palavras-chave: Adolescente; Brasil; Criança; Exercício; Estilo de vida sedentário.
1 Universidad Mayor. Centro de Investigación en Fisiologia del Ejercicio. Santiago. Chile / Major University. Center for Research in Exercise Physiology. Santiago. Chile.

2 Universidade Federal de São Paulo. São Paulo, São Paulo. Brasil / Federal University of Sao Paulo. Sao Paulo. Brazil.

3 Centro de Estudos do Laboratório de Aptidão Física de São Caetano do Sul. São Caetano do Sul, São Paulo. Brasil / Center for Physical Fitness Laboratory Studies of São Caetano do Sul, Sao Caetano do Sul, Sao Paulo. Brazil.

4 Universidade de São Paulo. Faculdade de Saúde Pública. São Paulo. Brasil / University of São Paulo. Public Health Faculty. Sao Paulo. Brazil.

Received: April 17, 2018 Accepted: July 10, 2018 


\section{INTRODUCTION}

It is estimated that only one in every three young Brazilians (13-17 years old) reach the daily recommendation for physical activity ${ }^{1}$. Research shows that children and adolescents that are involved in active transportation to school (ATS), such as walking and biking, accumulate more physical activities and have lower risks of being overweight and obese, of having a metabolic syndrome and diabetes than those who use motorized transportation, such as a car or bus ${ }^{2-4}$.

Despite the potential benefits for one's health, studies from other countries, including Brazil, reported a decline in the proportion of children and adolescents who use ATS in the past few decades ${ }^{5,6}$. ATS has been independently associated to higher levels of physical activity and lower levels of body fat and obesity in adolescents. However, longitudinal studies that analyze the behavior of these variables over the course of years are necessary to clarify this relation ${ }^{2}$. Due to the global decline in physical activity and increase in sedentary behavior in the past decade, the promotion of ATS has become an important topic, since it is part of the international initiatives aimed at increasing the level of physical activity in the population ${ }^{2,7,8}$.

Though there is growing evidence about ATS in children and adolescents, most of this evidence has come from high-income countries, such as Canada, USA, Australia and European countries ${ }^{5,6,9-11}$. This information can inform public health authorities for the implementation and promotion of ATS to combat excess weight and child obesity, in addition to chronic degenerative diseases associated to the lack of physical activities ${ }^{12}$. However, there is a lack of evidence in low- and middle-income countries, including Brazil regarding ATS.

In the past few decades, Brazil has undergone rapid urbanization with significant challenges in terms of transportation and urban planning ${ }^{13}$. In the past few years, in different ways throughout Brazil, there have been attempts to improve the characteristics of the urban environment and reduce the social impact on the population ${ }^{13}$. These initiatives have a major potential to promote active transportation. For example, factors such as neighborhoods far from the destination, disconnected streets, changes in the built environment and a lack of public safety are associated to lower $\mathrm{ATS}^{14}$. Moreover, differences by gender are prevalent in the literature on ATS $^{15,16}$. The results indicate that boys are more likely to use ATS than girls $^{16}$. The publication of these data may contribute to planning policies and programs that consider the regional characteristics of active transportation, as well as strategies to promote these practices. Hence, the objective of this study was to describe the use of ATS in Brazilian children and adolescents through a systematic review.

\section{METHODOLOGICAL PROCEDURES}

This revision was carried out from February to March of 2018 by searching 
the main databases in the area, governmental policies and research and by contacting researchers from this area.

The databases used were: 1) Latin American and Caribbean Health Sciences Literature (LILACS); 2) Regional Library of Medicine (BIREME); 3) Scientific Electronic Library Online (SCIELO); 4) Medical Literature Analysis and Retrieval System Online (MEDLINE), through PubMed; 5) and SciVerse Scopus (SCOPUS).

For the investigation of potential articles, we used the advanced search tool in each of the databases (searches performed using "keywords"), based on building blocks of descriptors created by the authors. The descriptors were entered in Portuguese, English and Spanish. The first block (result) was composed of terms referring to active transportation: "physical activity"; "transportation"; "commute"; "travel"; "use of time"; "active travel”; "active transportation”; "active commute”; "mobility”; "walk”; "biking”; "bike"; "bicycle"; "pedestrian"; "origin and destination"; "lifestyle". The second block included terms related to the target population of the study (children and adolescents): "child"; "children"; "adolescent”; "adolescents”; "preschool student"; "preschool students". The search was performed in articles published from January 2007 to December 2017.

The Boolean operator "OR" was used to add to the advanced search at least one word from each block and the operator "AND" to associate the blocks of keywords to one another. Moreover, the specific filters available in each of the databases searched were used.

The bibliography manager $E n d N o t e{ }^{\circledR} X 7$ software was used to create specific libraries, which enabled the identification and exclusion of duplicate studies, the division and organization of the results from each database.

The inclusion criteria were: original articles published in journals; articles that measured ATS; articles that measured active transportation and described the method used; and articles that evaluated Brazilian children and/or adolescents with ages ranging between 0 and 19 years of age (and/ or average age included in this range), without specific clinical conditions, without diagnoses of any diseases, non-athletes and those of both genders.

The article selection process was performed by a team of three researchers. First, by reading the titles and abstracts, we excluded articles that did not meet the inclusion criteria. Then, the articles selected in the first step were read in full to determine which studies still met the inclusion criteria and which were selected for the presentation of the results.

The risk of bias evaluation/methodological quality of the studies included was done by all three authors (TKF, ERV, GLMF), independently. The instrument used to evaluate the risk of bias/methodological quality was the questionnaire for cohort and transversal studies from the National Heart, Lung and Blood Institute ${ }^{17}$, which has 14 criteria to determine the risk of bias/ methodological quality of the study. This instrument evaluates the internal validity of the studies and includes questions that help to identify the possible risk of selection bias, information bias, measurement bias and confounding factors ${ }^{17}$. For each criterion evaluated, the scores 0 "no" and 1 "yes" were 
given. A total score was given to each study based on the number of positive answers to the questions in relation to the total number of questions ${ }^{18}$. The questions on the questionnaire that could not be answered by the available information and/or, that were not applicable to the study evaluated and/or aspects that had not been reported were excluded from the calculation to determine the final score of the methodological quality/risk of bias ${ }^{18}$.

According to the subjective evaluation of the reviewers, the studies were classified as having good methodological quality/low risk of bias (final score $\geq 0.70$ ), moderate methodological quality/moderate risk of bias (final score $\geqq 0.50$ ), low methodological quality/high risk of bias (final score < $0.50)^{20}$. The reviewers applied the evaluation instrument for methodological quality/risk of bias to all the studies that met the inclusion criteria, while disagreements between the reviewers in relation to the evaluation of a determined study was resolved through discussion.

\section{RESULTS}

The systematic search for articles that investigated ATS in Brazilian children and adolescents identified 1435 studies. After evaluating the titles and abstracts of all the studies found, 33 articles were fully analyzed. A total of 14 articles were excluded due to omissions related to the topic, the age range, the nationality and to duplication. Finally, after the omissions, 19 articles were included in this review (Figure 1).

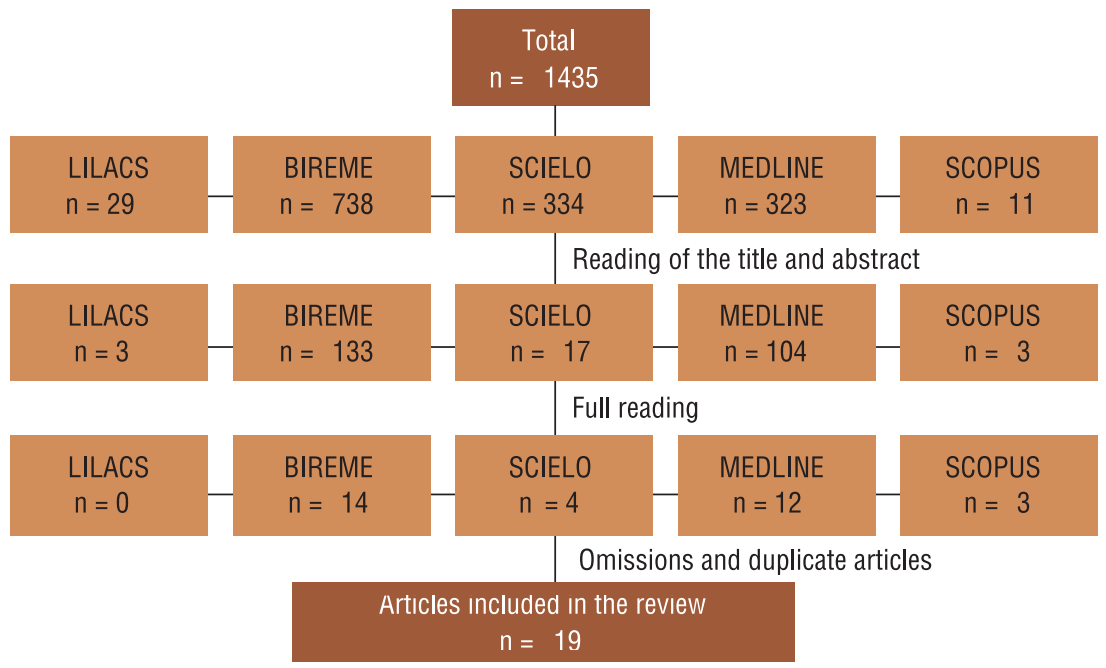

Figure 1. Search results for the data and criteria used in the selection of studies aimed at investigating active transportation for children and adolescents in Brazil.

Overall, of the 19 articles selected for this systematic review, 9 (47\%) showed that more than half of the students studied participated in active transportation, 6 (32\%) showed that less than half participated in active transportation, and 3 (16\%) presented only results separated by gender. Only 8 (42\%) of the 19 articles selected had values comparing males and females, while in 4 articles, the proportion of students who participated in active 
transportation was greater in males and in 4 it was greater in females (Table 1 ).

In relation to the year, 3 studies were from 2010 (16\%), 2011 (16\%) and 2014 (16\%), respectively; 2 were from 2008 (10\%), 2013 (10\%) and 2016 (10\%), respectively; and 1 was from 2009 (5,5\%), 2012 (5,5\%), 2015 (5,5\%) e 2017 (5,5\%), respectively.

Regarding the regions in Brazil, 11 (58\%) presented data from the South, 3 (16\%) studies presented data from the Southeast, 3 (16\%) from the Northeast and 2 (10\%) studies presented data from Brazil as a whole. The Northern and Midwestern regions were not studied in any of the articles selected.

In the South, of a total of 11 studies, 7 (64\%) indicated active transportation in more than half of the students. Upon analyzing the studies separately, all 5 studies carried out in Rio Grande do Sul had a higher percentage of active transportation among students. In Santa Catarina, of the 6 studies carried out, only 2 indicated active transportation in more than half of the students. In the Southeast, of a total of 3 studies, only 1 indicated active transportation in more than half of the students. In the Northeast, the two studies carried out had a higher number of students using active transportation. However, in the studies that presented national data, most students used passive transportation on their way to school.

Table 1. Cross-sectional studies with data from active or passive transportation in Brazilian schools between 2007 and 2017.

\begin{tabular}{|c|c|c|c|c|c|c|c|c|c|c|}
\hline \multirow[b]{2}{*}{ Author } & \multirow[b]{2}{*}{ Year } & \multirow{2}{*}{$\begin{array}{c}\text { Age } \\
\text { range } \\
\text { (years) }\end{array}$} & \multirow[b]{2}{*}{ Location } & \multirow[b]{2}{*}{$\begin{array}{c}\text { Sample } \\
\mathrm{n}\end{array}$} & \multicolumn{3}{|c|}{ Active transportation } & \multicolumn{3}{|c|}{ Passive transportation } \\
\hline & & & & & $\begin{array}{l}\text { Total } \\
\mathrm{n}(\%)\end{array}$ & $\begin{array}{l}\text { Male } \\
\mathrm{n}(\%)\end{array}$ & $\begin{array}{c}\text { Female } \\
\mathrm{n}(\%)\end{array}$ & $\begin{array}{l}\text { Total } \\
\mathrm{n}(\%)\end{array}$ & $\begin{array}{l}\text { Male } \\
\mathrm{n}(\%)\end{array}$ & $\begin{array}{c}\text { Female } \\
\mathrm{n}(\%)\end{array}$ \\
\hline Neto et al..$^{20}$ & 2014 & $7-10$ & $\begin{array}{c}\text { Vitória / Santa Maria de } \\
\text { Jetibá - ES }\end{array}$ & 1,770 & $63 \%$ & - & - & $37 \%$ & - & - \\
\hline Silva et al. ${ }^{21}$ & 2011 & $11-17$ & Caxias do Sul - RS & 1,675 & $62.5 \%$ & $66 \%$ & $59.3 \%$ & $37.5 \%$ & $34 \%$ & $40.7 \%$ \\
\hline Oliveira et al. ${ }^{22}$ & 2010 & $9-16$ & São Luís - MA & 592 & $58.4 \%$ & $56.8 \%$ & $60 \%$ & $41.6 \%$ & $43.2 \%$ & $40 \%$ \\
\hline Bergmann et al..$^{23}$ & 2011 & $7-12$ & Caxias do Sul - RS & 1,442 & $58.2 \%$ & - & - & $41.8 \%$ & - & - \\
\hline Ferrari et al..$^{15}$ & 2016 & $9-11$ & São Caetano do Sul - SP & 328 & $41.2 \%$ & - & - & $58.8 \%$ & - & - \\
\hline Silva et al. ${ }^{24}$ & 2008 & $7-12$ & João Pessoa - PB & 1,570 & $70 \%$ & - & - & $30 \%$ & - & - \\
\hline Kneipp et al..$^{25}$ & 2015 & $6-12$ & Itajaí - SC & 438 & $42.1 \%$ & - & - & $57.9 \%$ & - & - \\
\hline Benedet et al. ${ }^{26}$ & 2013 & $11-14$ & Florianopolis - SC & 1,590 & $46.5 \%$ & $22.7 \%$ & $23.8 \%$ & $53.2 \%$ & $24.5 \%$ & $28.7 \%$ \\
\hline Silva et al. ${ }^{27}$ & 2011 & $15-19$ & SC & 4,865 & $56.7 \%$ & $58.3 \%$ & $55.6 \%$ & $43.3 \%$ & $41.7 \%$ & $44.4 \%$ \\
\hline Silva et al. ${ }^{28}$ & 2009 & $15-19$ & SC & 5,028 & $56.7 \%$ & - & - & $43.3 \%$ & - & - \\
\hline Corso et al. ${ }^{29}$ & 2012 & $6-11$ & SC & 4,964 & $48.5 \%$ & - & - & $45.6 \%$ & - & - \\
\hline Pereira et al. ${ }^{30}$ & 2014 & $13-21$ & Santa Maria - RS & 1,126 & $61.8 \%$ & - & - & $38.2 \%$ & - & - \\
\hline Victo et al..$^{31}$ & 2017 & $11-18$ & Ilhabela - SP & 181 & $34.3 \%$ & $39.4 \%$ & $28.6 \%$ & $65.7 \%$ & $60.6 \%$ & $71.4 \%$ \\
\hline PNAD $^{32}$ & 2008 & $14-19$ & Brazil & 292,553 & $47.5 \%$ & - & - & - & - & - \\
\hline Dumith et al. ${ }^{33}$ & 2010 & $14-15$ & Pelotas-RS & 4,325 & $73.4 \%$ & $77.2 \%$ & $69.8 \%$ & $26.6 \%$ & $22.8 \%$ & $30.2 \%$ \\
\hline Santos et al..$^{34}$ & 2010 & 14- 19 & PE & 4,207 & $57 \%$ & $55 \%$ & $58.4 \%$ & $43 \%$ & $45 \%$ & $41.6 \%$ \\
\hline Castro et al. ${ }^{35}$ & 2016 & $14-19$ & São José - SC & 930 & $49.9 \%$ & - & - & $50.1 \%$ & - & - \\
\hline Bergmann et al. ${ }^{36}$ & 2013 & $10-17$ & Uruguaiana - RS & 1,343 & $75.7 \%$ & - & - & $24.3 \%$ & - & - \\
\hline Rezende et al. ${ }^{1}$ & 2014 & $7-10$ & Brazil & 109,104 & $49.9 \%$ & $50.9 \%$ & $49.2 \%$ & $38 \%$ & $36.1 \%$ & $39.8 \%$ \\
\hline
\end{tabular}




\section{DISCUSSION}

This study conducted an extensive review of the literature to estimate the prevalence of ATS in Brazilian children and adolescents. Active transportation is understood as a commute from one destination to another, which can be by walking, bicycle, roller skates, skate board and non-motorized wheelchairs. This type of transportation provides numerous benefits, as a way to promote health by increasing physical activities on a regular day. Moreover, it favors urban sustainability in major metropolises, reducing traffic, contributing to a reduction in the emission of gases and the greenhouse effect, and helping to save money on fuel and parking ${ }^{37}$.

The results show that the estimates of ATS vary greatly according to each study. Methodological variations were found in the different studies analyzed, mainly regarding the instrument used to collect the data and the criterion for evaluating active transportation. Moreover, some studies did not perform the analysis stratified by gender, making it difficult to identify the prevalence of ATS by gender.

Despite some of the studies showing that boys tend to use ATS more than girls ${ }^{27}$, this review showed a balance in this distribution. Overall, boys use ATS similarly to girls, with four studies indicating a longer active commute for the boys and 4 indicating a longer active commute among girls.

Similarly to what has been observed in other areas of knowledge, the concentration of studies on ATS is in the Southern, Southeastern and Northeastern regions, showing that there is a lack of data in the Midwestern and Northern regions, limiting the generalizability of the research results, since ATS and its associated factors may vary according to the geographical location.

Several factors may be considered barriers to the use of ATS, such as $=$ distance to the school, danger related to traffic and climate adversities of the $\operatorname{city}^{38}$. In Brazil, a low socioeconomic level has been associated to active commuting, with children and adolescents from higher socioeconomic levels using less active transportation due to the lack of safety ${ }^{39}$. When comparing urban and rural regions, a study showed that urban students use more transportation on foot, while rural students commute more with bicycles, buses or motor vehicles ${ }^{20}$. However, to better understand the use of ATS in different regions and socioeconomic levels, in addition to analyzing the type of active commuting, there need to be studies that analyze the commute time, the distance to the school and other environmental and urban mobility factors such as bike paths, traffic and conditions of the city.

The authors understand that this review has some limitations and strong points. Despite the research including 5 databases and being performed in three languages (English, Portuguese and Spanish), the estimates of ATS stratified by gender were not found in some studies. Despite the importance of the subject studied, only one government document provided information on ATS. All studies included failed to present an instrument to evaluate active transportation, contributing to the difficulty in evaluating 
the prevalence of children and adolescents that participate in this type of transportation. However, there was an evaluation of the quality or risk of bias in all the studies that were selected, with 2 having a moderate risk of bias and 17 had a low risk of bias. Despite the studies having a low and moderate risk of bias, they still highlight the need for a better study design and more transparency in the reports.

The authors recommend the inclusion of standardized measures, which can be a challenge for researchers of public health and transportation. Moreover, the authors recommend the use of devices that use mobile GPS and speedometers to objectively measure active transportation; performing transversal and wide-ranging research, with representative samples in lowand middle-income countries, in rural and urban populations; performing longitudinal research capable of establishing the determinants of active transportation; and performing qualitative analyses that also investigate culture, commuting and infrastructure standards.

\section{CONCLUSION}

Based on the results of this review, the prevalence of ATS for Brazilian children and adolescents varies according to the studies and regions in Brazil. Overall, boys use ATS similarly to girls, with 4 studies for each gender. Local ATS authorities should be encouraged to build monitoring systems on sources of information to generate standardized and detailed reports on ATS to support planning and evaluate public policies. This type of information may help in the fight against physical inactivity.

\section{COMPLIANCE WITH ETHICAL STANDARDS}

\section{Funding}

This research did not receive any specific grant from funding agencies in the public, commercial, or not-for-profit sectors. This study was funded by the authors.

\section{Conflict of interest statement}

The authors have no conflict of interests to declare.

\section{Author Contributions}

Conceived and designed the experiments: GLMF. Performed the experiments: ERV and TKF. Analyzed the data: DS. Contributed reagents/ materials/analysis tools: GLMF and DS. Wrote the paper: GLMF, ERV and TKF.

\section{REFERENCES}

1. Rezende LF, Azeredo CM, Canella DS, Claro RM, de Castro IR, Levy RB, et al. Sociodemographic and behavioral factors associated with physical activity in Brazilian adolescents. BMC Public Health 2014;14(1):485. 
2. Mendoza JA, Watson K, Nguyen N, Cerin E, Baranowski T, Nicklas TA. Active commuting to school and association with physical activity and adiposity among US youth. J Phys Act Health 2011;8(4):488-95.

3. Pizarro AN, Ribeiro JC, Marques EA, Mota J, Santos MP. Is walking to school associated with improved metabolic health? Int J Behav Nutr Phys Act 2013;10:12.

4. Larouche R, Saunders TJ, Faulkner G, Colley R, Tremblay M. Associations between active school transport and physical activity, body composition, and cardiovascular fitness: a systematic review of 68 studies. J Phys Act Health 2014;11(1):206-27.

5. Buliung RN, Mitra R, Faulkner G. Active school transportation in the Greater Toronto Area, Canada: an exploration of trends in space and time (1986-2006). Prev Med 2009;48(6):507-12.

6. Faulkner GE, Buliung RN, Flora PK, Fusco C. Active school transport, physical activity levels and body weight of children and youth: a systematic review. Prev Med 2009;48(1):3-8.

7. $\mathrm{Ng} \mathrm{SW}$, Popkin BM. Time use and physical activity: a shift away from movement across the globe. Obes Rev 2012;13(8):659-80.

8. Kalman M, Inchley J, Sigmundova D, Iannotti RJ, Tynjala JA, Hamrik Z, et al. Secular trends in moderate-to-vigorous physical activity in 32 countries from 2002 to 2010: a cross-national perspective. Eur J Public Health 2015;25 (Suppl 2):37-40.

9. McDonald NC, Steiner RL, Lee C, Rhoulac Smith T, Zhu X, Yang Y. Impact of the safe routes to school program on walking and bicycling. J Am Plan Assoc 2014; 80(2):153-67

10. Bringolf-Isler B, Grize L, Mader U, Ruch N, Sennhauser FH, Braun-Fahrlander $\mathrm{C}$, et al. Personal and environmental factors associated with active commuting to school in Switzerland. Prev Med 2008;46(1):67-73.

11. Vanwolleghem G, Van Dyck D, De Meester F, De Bourdeaudhuij I, Cardon G, Gheysen F. Which Socio-Ecological Factors Associate with a Switch to or Maintenance of Active and Passive Transport during the Transition from Primary to Secondary School? PloS One 2016;11(5):e0156531.

12. Sigmund E, Sigmundova D, Badura P, Kalman M, Hamrik Z, Pavelka J. Temporal Trends in Overweight and Obesity, Physical Activity and Screen Time among Czech Adolescents from 2002 to 2014: A National Health Behaviour in SchoolAged Children Study. Int J Environ Res Public Health 2015;12(9):11848-68.

13. Gomez LF, Sarmiento R, Ordonez MF, Pardo CF, de Sa TH, Mallarino CH, et al. Urban environment interventions linked to the promotion of physical activity: a mixed methods study applied to the urban context of Latin America. Soc Sci Med 2015;131:18-30.

14. Saelens BE, Sallis JF, Frank LD. Environmental correlates of walking and cycling: findings from the transportation, urban design, and planning literatures. Ann Behav Med 2003;25(2):80-91.

15. Ferrari GL, Matsudo V, Barreira TV, Tudor-Locke C, Katzmarzyk PT, Fisberg M. Correlates of Moderate-to-Vigorous Physical Activity in Brazilian Children. J Phys Act Health. 2016;13(10):1132-45.

16. Yang Y, Ivey SS, Levy MC, Royne MB, Klesges LM. Active Travel to School: Findings From the Survey of US Health Behavior in School-Aged Children, 2009-2010. J Sch Health 2016;86(6):464-71.

17. National Heart, Lung and Blood Institute. Quality assessment tool for observational cohort and cross-sectional studies. Bethesda: National Institutes of Health, Department of Health and Human Services. 2014.

18. Tan SS, Goonawardene N. Internet Health Information Seeking and the PatientPhysician Relationship: A Systematic Review. J Med Internet Res 2017;19(1):e9.

19. Ismail Z, Elbayoumi H, Fischer CE, Hogan DB, Millikin CP, Schweizer T, et al. Prevalence of Depression in Patients With Mild Cognitive Impairment: A Systematic Review and Meta-analysis. JAMA Psychiatry 2017;74(1):58-67. 
20. Andrade Neto F, Eto FN, Pereira TS, Carletti L, Molina Mdel C. Active and sedentary behaviours in children aged 7 to 10 years old: the urban and rural contexts, Brazil. BMC Public Health 2014;14:1174.

21. Silva KS, Vasques DG, Martins Cde O, Williams LA, Lopes AS. Active commuting: prevalence, barriers, and associated variables. J Phys Act Health 2011;8(6):750-7.

22. Oliveira TC, Silva AA, Santos Cde J, Silva JS, Conceição SI. Physical activity and sedentary lifestyle among children from private and public schools in Northern Brazil. Rev Saude Publica 2010;44(6):996-1004.

23. Bergmann ML, Bergmann GG, Halpern R, Rech RR, Constanzi CB, Alli LR. Associated factors to total cholesterol: school based study in southern Brazil. Arq Bras Cardiol 2011;97(1):17-25.

24. Silva KS, Lopes AS. Excess weight, arterial pressure and physical activity in commuting to school: correlations. Arq Bras Cardiol 2008;91(2):84-91.

25. Kneipp C, Habitzreuter F, Mezadri T, Hofelmann DA. Overweight and associated variables in schoolchildren in Itajai in the State of Santa Catarina, Brazil. Ciênc Saúde Colet 2015;20(8):2411-22.

26. Benedet J, Assis MA, Calvo MC, Andrade DF. Overweight in adolescents: exploring potential risk factors. Rev Paul Pediatr 2013;31(2):172-81.

27. Silva KS, Nahas MV, Borgatto AF, Oliveira ES, Del Duca GF, Lopes AS. Factors associated with active commuting to school and to work among Brazilian adolescents. J Phys Act Health 2011;8(7):926-33.

28. Silva KS, Nahas MV, Peres KG, Lopes AdS. Fatores associados à atividade física, comportamento sedentário e participação na Educação Física em estudantes do Ensino Médio em Santa Catarina, Brasil. Cad Saúde Pública 2009;25(10):2187-200.

29. Corso ACT, Caldeira GV, Fiates GMR, Schmitz BdAS, Ricardo GD, Vasconcelos FdAGd. Fatores comportamentais associados ao sobrepeso e à obesidade em escolares do Estado de Santa Catarina. Rev Bras Estud Popul 2012;29:117-31.

30. Pereira EF, Moreno C, Louzada FM. Increased commuting to school time reduces sleep duration in adolescents. Chronobiol Int 2014;31(1):87-94.

31. Victo ER, Ferrari GLM, Silva JPDJ, Araujo TL, Matsudo VKR. Lifestyle Indicators and Cardiorespiratory Fitness in Adolescents. Rev Paul Pediatr 2017;35(1):61-8.

32. Pesquisa Nacional por Amostra de Domicílio. Um panorama da saúde no Brasil. Acesso e utilização dos serviços, condições de saúde e fatores de risco e proteção à saúde: Ministério da Saúde, Brasil. 2008.; avaiable from: <https://biblioteca.ibge. gov.br/visualizacao/monografias/GEBIS\%20-\%20RJ/panorama.pdf> [2018 jun15].

33. Dumith SC, Domingues MR, Gigante DP, Hallal PC, Menezes AMB, Kohl HW. Prevalence and correlates of physical activity among adolescents from Southern Brazil. Rev Saude Publica 2010;44(3).

34. Santos CM, de Souza Wanderley Junior R, Barros SS, de Farias Junior JC, de Barros MV. Prevalence of physical inactivity and associated factors among adolescents commuting to school. Cad Saúde Pública 2010;26(7):1419-30.

35. Castro JA, Nunes HE, Silva DA. Prevalence of abdominal obesity in adolescents: association between sociodemographic factors and lifestyle. Rev Paul Pediatr 2016;34(3):343-51.

36. Bergmann GG, Bergmann MLdA, Marques AC, Hallal PC. Prevalence of physical inactivity and associated factors among adolescents from public schools in Uruguaiana, Rio Grande do Sul State, Brazil. Cad Saúde Pública 2013;29(11):2217-29.

37. Giles-Corti B, Foster S, Shilton T, Falconer R. The co-benefits for health of investing in active transportation. N S W Public Health Bull. 2010;21(5-6):122-7

38. Centers for Disease C, Prevention. Barriers to children walking to or from school--United States, 2004. MMWR Morbidity and mortality weekly report. 2005;54(38):949-52.

39. Hallal PC, Bertoldi AD, Goncalves H, Victora CG. Prevalence of sedentary lifestyle and associated factors in adolescents 10 to 12 years of age. Cad Saúde Pública 2006;22(6):1277-87.
CORRESPONDING AUTHOR

Gerson Ferrari

Rua Otonis, 725- Vila Clementino CEP: 04025-002 - Sao Paulo - Sao Paulo - Brazil

E-mail: gersonferrari08@yahoo. com.br 